AperTO - Archivio Istituzionale Open Access dell'Università di Torino

\title{
Maternal obesity and childhood wheezing and asthma
}

\section{This is a pre print version of the following article:}

Original Citation:

Availability:

This version is available http://hdl.handle.net/2318/1647558

since 2020-06-16T17:06:13Z

Published version:

DOI:10.1016/j.prrv.2016.08.009

Terms of use:

Open Access

Anyone can freely access the full text of works made available as "Open Access". Works made available under a Creative Commons license can be used according to the terms and conditions of said license. Use of all other works requires consent of the right holder (author or publisher) if not exempted from copyright protection by the applicable law. 


\section{IIIS AperTO}

UNIVERSITÀ

DEGLI STUDI

DI TORINO

This is the author's final version of the contribution published as:

Rusconi F, Popopvic M. Maternal obesity and childhood wheezing and asthma. Paediatr Respir Rev. 2017;22:66-71. doi: 10.1016/j.prrv.2016.08.009.

The publisher's version is available at:

https://www.sciencedirect.com/science/article/abs/pii/S1526054216300835?via\%3Dihub

When citing, please refer to the published version.

Link to this full text:

http://hdl.handle.net/2318/1647558

This full text was downloaded from iris-Aperto: https://iris.unito.it/

Maternal obesity and childhood wheezing and asthma 
Franca Rusconi ${ }^{1},{ }^{*}$ Maja Popovic ${ }^{2}$

${ }^{1}$ Unit of Epidemiology, 'Anna Meyer' Children’s University Hospital, Florence, Italy

2 Department of Medical Sciences, University of Turin, Turin, Italy

\section{* Corresponding author}

Franca Rusconi

Epidemiology Unit

Anna Meyer Children's University Hospital

Viale Pieraccini 24

50139 Florence, Italy.

Tel.: +39055 5662556;

fax: +390555662559

E-mail address: franca.rusconi@meyer.it

\section{EDUCATIONAL AIMS}

The reader will come to appreciate how:

- To review the epidemiologic evidence on the impact of maternal obesity on childhood wheezing and asthma from recent birth cohort studies.

- To discuss potential mechanisms and pathways between maternal obesity and childhood wheezing and asthma.

\section{S U M M A R Y}

Obesity represents one of the major public health problems worldwide, with an increased prevalence also among women of reproductive age. Maternal pre-pregnancy overweight and obesity are important risk factors for a number of maternal and foetal/neonatal complications. The objective of this review is to provide an overview of the most recent evidence regarding the associations between pre-pregnancy overweight/obesity and wheezing and asthma in childhood. Potential mechanisms, mediators and confounding factors involved in these associations are also discussed. Despite the relatively large body of studies 
examining these associations and taking into account main confounders and potential mediators, the causal relationship between maternal obesity and wheezing and asthma in childhood is still uncertain. This uncertainty is not trivial, as any prevention strategy aimed at reducing the burden of these conditions would necessarily imply better understanding of the factors that are in the causal chain.

Keywords: Maternal obesity, wheezing, asthma, foetal programming, cohort studies

\section{INTRODUCTION}


There is growing evidence on the relationship between early life factors and a wide range of chronic diseases in children and adults [1,2], including obstructive lung disease and asthma [1,3]. The greater impact of maternal compared to paternal asthma and atopy on the development of wheezing and asthma in offspring also suggests a role of prenatal and in utero environment [2]. Developmental adaptations in foetal life might result in impaired lung growth, and consequently, an increased risk of wheezing and asthma later in life. In addition, pregnancy and perinatal factors affecting the development of the foetal and infant immune system might play a role in the development of respiratory diseases [4,5]. Studies performed in different countries highlighted an increasing trend in the prevalence of several pre-existing and pregnancy related pathologies, including maternal overweight and obesity [6,7]. Obesity represents one of the major public health problems worldwide [8], with an increased prevalence also among women of reproductive age. In western countries, the obesity prevalence in pregnant women has been reported to be up to $30 \%$ [9]; while up to $40 \%$ of women gain an excessive weight during pregnancy [10].

Maternal pre-pregnancy overweight and obesity and, to a lesser extent, excessive gestational weight gain, are important risk factors for a number of maternal and foetal/neonatal complications [11]. The objective of this review is to provide an overview of the most recent evidence regarding the associations between pre-pregnancy overweight/obesity and wheezing and asthma in childhood. We will further discuss potential mechanisms, mediators and confounding factors involved in these associations. This review is also intended to expand and integrate a previous review on maternal obesity and immune dysregulation in mother and infant [12].

\section{FINDINGS FROM LONGITUDINAL STUDIES}

In the past decades many pregnancy and birth cohort studies have been established in Europe [13]. One of the main aims is to gather information on pregnancy and perinatal exposures, and to prospectively collect data on child's development, and on the occurrence of a number of diseases. Over time, these cohorts became a precious source of data for conducting studies on potential risk factors for the development of later outcomes in childhood and adulthood. The majority of cohorts collected data on maternal anthropometric measurements, usually maternal weight and height, before pregnancy or in early pregnancy. Maternal overweight and obesity are generally defined based on the body mass index (BMI) and according to the World Health Organization (WHO) definitions: overweight as BMI between 25 and $29.9 \mathrm{~kg} / \mathrm{m} 2$, obesity as BMI $\geq 30 \mathrm{~kg} / \mathrm{m} 2$ [14].

Wheezing is one of the most common respiratory symptoms in early childhood with approximately $30 \%$ children having at least one wheezing episode in the first 3 years of life [15]. The differential diagnosis of wheezing is extensive and several temporal phenotypes have been described [16,17]. The birth cohort studies assessed child's wheezing and asthma at different ages, from the first months of life until adolescence. Wheezing occurring in the pre-schoolers is regarded as a distinct phenomenon, and at least in part is accompanied by a narrowing (or relative narrowing) of the distal airways. Most of the infants who wheeze in their first years recover before school age, though sometimes, typically when accompanied with atopy and a more severe clinical course, these children continue to wheeze beyond infancy and can be labelled as asthmatics. Although less commonly, wheezing could also start later and as such is usually linked to an atopic background.

In line with these temporal phenotypes we will discuss the existing evidence regarding maternal obesity and preschool and school-aged wheezing separately. 


\section{Maternal obesity and preschool wheezing}

Studies generally support the positive association between maternal obesity and wheezing in the first years of life in offspring (Table 1) [18-29]. These associations were independent of common confounding factors and potential mediators such as birth weight and child's BMI, atopic background and obesity-related pregnancy complications.

In a large Norwegian study [18], conducted on 32,192 children, maternal obesity, defined as BMI $\geq 30$, was associated with wheezing in 18-month old children (adjusted RD = 3.3; 95\%CI: 1.2-5.3). The authors adjusted for a large number of confounding factors, such as maternal age, education, parity, smoking and history of asthma, and the association was not mediated neither by pregnancy complications, caesarean section, premature birth or child's birth weight. However, they did not take into account child's growth in the first 18 months of life that could mediate the associations between maternal BMI and early childhood wheezing. Similar findings, adjusted for child's weight-for length (WFL) z-scores were reported also by Guerra et al. [21], but only for frequent episodes of wheeze ( $\geq 4$ episodes) in the first 14 months of life.

Although asthma diagnosis in preschool age is rather uncertain, Reichman et al. [29] reported a 1.5fold increased risk of parent-reported asthma diagnosis in 3-year-old children born to obese mothers. In a recent study conducted on 2606 children [26] a higher maternal BMI was associated with an increased risk of childhood wheezing in the first year of life; the association was largely explained by impaired lung function, especially in children of non-atopic mothers. However, lung function was of minor influence compared to child's anthropometrics for the associations between maternal obesity and consultations and prescriptions for wheezing illnesses in 5-year-olds.

In a pooled analysis of 85,509 children from 14 European birth cohorts [13], maternal pre-pregnancy overweight and obesity were both positively associated with any wheezing (overweight $\mathrm{OR}=1.08$; 95\% CI: $1.05-1.11$, obesity OR=1.12; 95\% CI: 1.08-1.17) and recurrent wheezing in the first two years of life (overweight $\mathrm{OR}=1.19 ; 95 \% \mathrm{CI}: 1.12-1.26$, obesity $\mathrm{OR}=1.16$; 95\% CI: 0.97-1.39). These associations were independent of several pregnancy complications and the results changed only moderately after taking into account potential mediators, such as child's birth weight, gestational age, delivery mode and breastfeeding.

Although studies that assessed maternal BMI as a continuous variable suggest that the risk of early wheeze rise progressively with an increase in maternal BMI [29-32] other studies found the effect for maternal obesity (BMI $>30 \mathrm{~kg} / \mathrm{m} 2$ ) and not for overweight (BMI 25-29.9 kg/m2) [23,24,26,27]. However, two large studies $[13,28]$ confirmed that also children of mothers who are overweight suffer more from wheezing compared to children born to mothers of normal weight. Moreover, most of the studies found that maternal obesity is a risk factor for both transient and recurrent wheezing in the first years of life.

Maternal history of asthma and atopy were usually considered as potential confounders but the adjustment rarely attenuated the associations found between pre-pregnancy obesity and early wheezing. However, Leermakers et al. [27] stratified the analyses by maternal history of asthma and atopy and found that maternal pre-pregnancy BMI was associated with an overall increased risk of preschool wheezing only in children with familial asthma or atopy predisposition. Other potential mediating factors, such as pregnancy and delivery complications, child's birth weight and current BMI had a minor influence on the observed associations. 
Table 1. Studies reporting associations between maternal overweight/obesity and preschool wheezing

\begin{tabular}{|c|c|c|c|}
\hline Author & "Subjects & " Outcome & "Main results \\
\hline $\begin{array}{l}\text { Haberg et al. } \\
\quad 200923\end{array}$ & 32,281 & Wheeze 6-18 months & $\begin{array}{l}\text { Positive associations between wheezing and maternal } \\
\text { obesity but not overweight. The association was not } \\
\text { mediated by pregnancy complications, low birth } \\
\text { weight, preterm birth or caesarean section. }\end{array}$ \\
\hline $\begin{array}{l}\text { Kumar et al. } \\
\quad 2010\end{array}$ & 1,191 & Recurrent wheeze $0-3$ years & $\begin{array}{l}\text { Positive associations between wheezing and maternal } \\
\text { obesity but not overweight. The results were not } \\
\text { attenuated after adjustment for child's atopy. Child's } \\
\text { BMI slightly attenuated the effects. }\end{array}$ \\
\hline $\begin{array}{l}\text { Wright et al. } \\
2013^{25}\end{array}$ & 261 & Repeated wheeze $0-2$ years & $\begin{array}{l}\text { The association between wheezing and maternal } \\
\mathrm{BMI} \geq 30 \text { was borderline significant. }\end{array}$ \\
\hline $\begin{array}{l}\text { Guerra et al. } \\
\qquad 2013^{26}\end{array}$ & 1,107 & $\begin{array}{l}\text { Frequent wheeze ( } \geq 4 \\
\text { episodes) and infrequent } \\
\text { wheeze ( }<4 \text { episodes) up to } 14 \\
\text { months }\end{array}$ & $\begin{array}{l}\text { No association between maternal overweight/obesity } \\
\text { and infrequent wheeze. For frequent wheeze the } \\
\text { positive association was found for maternal obesity but } \\
\text { not for overweight. The associations persisted after } \\
\text { taking into account child's WFL z-scores. }\end{array}$ \\
\hline $\begin{array}{l}\text { Leermakers } \\
\text { et al. } 2013^{27}\end{array}$ & 4,656 & $\begin{array}{l}\text { Wheezing at 1, 2, } 3 \text { and } 4 \\
\text { years }\end{array}$ & $\begin{array}{l}\text { Associations found only for wheezing at the age of } 4 \\
\text { years. Obesity was associated with an overall risk of } \\
\text { preschool wheezing only among children of mothers } \\
\text { with history of asthma/atopy. Infections, child's growth } \\
\text { and eczema did not modify the observed associations. }\end{array}$ \\
\hline $\begin{array}{l}\text { Harpsoe et } \\
\text { al. } 2013^{28}\end{array}$ & 38,874 & $\begin{array}{l}\text { Early transient wheeze at } 18 \\
\text { months (assessed until } 7 \\
\text { years) }\end{array}$ & $\begin{array}{l}\text { Both overweight and obesity were associated with } \\
\text { early transient wheezing. }\end{array}$ \\
\hline $\begin{array}{l}\text { Caudri et al. } \\
2013^{29}\end{array}$ & 2,728 & $\begin{array}{l}\text { Transient early wheeze } \\
\text { (wheeze assessed annually } \\
\text { until } 8 \text { years) }\end{array}$ & $\begin{array}{l}\text { After adjustment the association with maternal BMI } \\
\text { remained only for early transient wheeze and } \\
\text { borderline for persistent wheeze. }\end{array}$ \\
\hline $\begin{array}{l}\text { Pike et al. } \\
2013^{30}\end{array}$ & 934 & $\begin{array}{l}\text { Transient wheeze in the first } 3 \\
\text { years (wheeze assessed until } 6 \\
\text { years) }\end{array}$ & $\begin{array}{l}\text { Maternal fat mass (skin fold thickness) and BMI were } \\
\text { associated with transient wheeze. Adjustment for } \\
\text { infant adiposity gain or BMI at } 3 \text { or } 6 \text { years did not } \\
\text { alter the results. }\end{array}$ \\
\hline $\begin{array}{l}\text { de Vries et } \\
\text { al. } 2014^{32}\end{array}$ & 4,860 & $\begin{array}{l}\text { Wheezing in the first } 5 \text { months } \\
\text { of age }\end{array}$ & $\begin{array}{l}\text { Maternal BMI was associated with offspring wheezing. } \\
\text { Maternal cortisol levels did not mediate this } \\
\text { association. }\end{array}$ \\
\hline $\begin{array}{l}\text { Zugna et al. } \\
2015^{13}\end{array}$ & 85,509 & $\begin{array}{l}\text { Wheezing between birth and } \\
\text { 12-24 months }\end{array}$ & $\begin{array}{l}\text { In a pooled analysis of } 14 \text { European birth cohorts } \\
\text { maternal pre-pregnancy overweight and obesity were } \\
\text { both associated with an increased risk of ever and } \\
\text { recurrent wheezing in the offspring. }\end{array}$ \\
\hline $\begin{array}{c}\text { Eising et al. } \\
2015^{31}\end{array}$ & 2,606 & $\begin{array}{l}\text { Wheezing in the first year of } \\
\text { life and at the age of } 5 \\
\text { (consultations and } \\
\text { prescriptions) }\end{array}$ & $\begin{array}{l}\text { Maternal BMI was associated with an increased risk of } \\
\text { wheezing in the } 1^{\text {st }} \text { year of life and more consultations } \\
\text { and prescriptions for wheezing until the age of } 5 \text { years. } \\
\text { In the } 1^{\text {st }} \text { year of life the association is largely } \\
\text { explained by an impaired lung function, especially in } \\
\text { children of non-atopic mothers. At the age of } 5 \text { years } \\
\text { child's current anthropometrics slightly changed the } \\
\text { results. }\end{array}$ \\
\hline
\end{tabular}


The evidence supporting an association between maternal obesity and persistence of wheezing symptoms in older children is less conclusive (Table 2). Pike et al. found no association between maternal adiposity and persistent wheezing or doctor-diagnosed asthma the age of six years [30]. No association was found for late-onset wheezing and only borderline effect for wheezing persisting until the age of eight years was found in children from the PIAMA cohort study [29]. In the study of Sholtens et al. [34] maternal pre-pregnancy BMI (as a continuous measurement) and overweight defined as $B M I \geq 25 \mathrm{~kg} / \mathrm{m} 2$ were positively associated with childhood wheeze and asthma at 8 years of age, but the effect was evident only in children who were at high risk due to a positive family history of asthma.

On the contrary, a study of 38,874 children from Denmark [28] showed that both increased prepregnancy maternal weight and gestational weight gain when mutually adjusted were independently associated with persistent and late-onset wheeze, as well as with childhood asthma assessed at the age of 7 years. In a large cohort study from the Netherlands, maternal obesity, but not overweight was associated with current wheezing and ever asthma diagnosed by a doctor in 7-8 years old children [35]. The effect of maternal obesity on childhood current wheezing was both direct and mediated through child's BMI, while the effect on ever asthma was not mediated through child's BMI. They found no interaction/effect modification by parental history of asthma.

A recent meta-analysis [36] that included 108,321 mother-child pairs from fourteen observational studies confirmed the effect of maternal obesity on childhood ever wheeze/asthma $(\mathrm{OR}=1.49$; $95 \% \mathrm{CI}$ : 1.22-1.83) and current wheeze/asthma (OR=1.35; 95\%CI: 1.08-1.68). The effects of maternal overweight were borderline significant for both ever and current wheeze/asthma. It should be noted that there was a significant heterogeneity among the studies included in the meta-analysis with the outcomes measured from birth until 18 years of age.

In brief, the association between maternal obesity and persistence of wheezing at school age is still controversial. It appears that the effect of maternal overweight/obesity on wheezing in offspring is more pronounced in the first years of life and that the effects seen in older children are less evident for overweight than for obesity. Moreover, it seems that the effects on wheezing at school age are more likely mediated through child's overweight and obesity.

Table 2. Studies reporting associations between maternal overweight/obesity and wheezing in schoolaged children

\begin{tabular}{cccl}
\hline \hline Author & Subjects & Outcome & \multicolumn{1}{c}{ Main results } \\
\hline \hline $\begin{array}{c}\text { Scholtens et } \\
\text { al. 2010 } \text { 34 }^{34}\end{array}$ & 3963 & $\begin{array}{c}\text { Wheeze and } \\
\text { asthma at 8 years }\end{array}$ & $\begin{array}{l}\text { Wheeze and asthma were associated with maternal } \\
\text { BMI } \geq 25 \text { only in children with positive family history of } \\
\text { asthma. Birth weight and child's BMI slightly attenuated } \\
\text { the observed associations. They found no associations }\end{array}$ \\
\hline
\end{tabular}


with sensitization to inhalant allergens and bronchial

hyper-responsiveness.

\begin{tabular}{|c|c|c|c|}
\hline $\begin{array}{c}\text { Harpsoe et } \\
\text { al. } 2013^{28}\end{array}$ & 38874 & $\begin{array}{l}\text { Persistent and } \\
\text { late-onset wheeze } \\
\text { (assessed at } 18 \\
\text { months and } 7 \\
\text { years) }\end{array}$ & $\begin{array}{l}\text { Both overweight and obesity were associated with } \\
\text { persistent wheeze and late-onset wheeze. They also found } \\
\text { an association with doctor-diagnosed ever and current } \\
\text { asthma and no association with atopic eczema or hay } \\
\text { fever. }\end{array}$ \\
\hline $\begin{array}{l}\text { Pike et al. } \\
2013^{30}\end{array}$ & 934 & $\begin{array}{l}\text { Persistent wheeze } \\
\text { (<3 years and at } 6 \\
\text { years) }\end{array}$ & $\begin{array}{l}\text { The positive associations found between maternal BMI } \\
\text { and transient and ever wheeze only. No associations with } \\
\text { ever or current asthma, current or persistent wheeze, } \\
\text { child's atopy, exhaled nitric oxide or spirometry. } \\
\text { Adjustment for infant adiposity gain or BMI did not alter } \\
\text { the results. }\end{array}$ \\
\hline $\begin{array}{c}\text { Caudri et al. } \\
2013^{29}\end{array}$ & 2728 & $\begin{array}{l}\text { Persistent wheeze } \\
\text { and late onset at } 8 \\
\text { years (assessed } \\
\text { annually) }\end{array}$ & $\begin{array}{l}\text { They found a positive association between maternal BMI } \\
\text { and persistent wheeze, but not late-onset wheeze. After } \\
\text { adjustment the associations remained only borderline } \\
\text { significant for persistent wheeze. }\end{array}$ \\
\hline $\begin{array}{l}\text { Harskamp- } \\
\text { van Ginkel et } \\
\text { al. } 2015^{35}\end{array}$ & 3185 & $\begin{array}{l}\text { Wheeze and } \\
\text { asthma in the first } \\
\text { 7-8 years }\end{array}$ & $\begin{array}{l}\text { Maternal pre-pregnancy obesity was associated with } \\
\text { higher risks of both asthma and wheezing. Offspring BMI } \\
\text { was a mediator in the association between maternal BMI } \\
\text { and offspring wheezing, but not for asthma. There was no } \\
\text { interaction by parental asthma. }\end{array}$ \\
\hline
\end{tabular}

\section{Maternal obesity and asthma in childhood and adolescence}

Some of the studies discussed in the previous section found an effect of maternal overweight and obesity also on asthma diagnosis in school-aged children [28,34,35].

Several other studies evaluated the associations between maternal obesity and asthma in older children [37-41]. In a registry-based study of 189,783 children born in Stockholm, Sweden Lowe et al. found that higher maternal BMI was consistently associated with an increased risk of asthma in the child [37]. They assessed asthma in terms of asthma medication use and hospitalization at different ages during the first ten years of life. At age 6 to 8 years, the effect of maternal BMI was somewhat stronger in girls than in boys.

Maternal BMI was associated with current wheezing and asthma also in adolescents but only among those without parental history of atopy [38]. These results were contrary to those reported by Scholtens et al. [34] that found an association between maternal overweight (BMI $\geq 25 \mathrm{~kg} / \mathrm{m} 2 \mathrm{vs}$. normal weight) with wheeze and asthma only in children born to parents with asthma or allergy. The discrepancy between these two findings might be due to different age groups of children (adolescents vs. school-aged children), different phenotypic characteristics or potential residual confounding.

A recent study from the United States [41] found that both maternal overweight and obesity increased the overall risk of asthma in children up to 18 years of age, but in asthma subtype analysis the associations were seen only for asthma onset before 12 years of age. Moreover, after stratification by allergic background the associations were stronger for asthma without allergic background compared to the allergic one. Additionally, they reported sex-specific patterns for the associations with allergic 
and non-allergic asthma: the association was observed with non-allergic asthma only in boys and with allergic asthma only in girls.

A positive association between maternal BMI and asthma in 16-year-olds was also confirmed by Ekström et al. [40]; in this study adolescent's overweight mediated to some extent the observed association.

\section{POTENTIAL MECHANISMS AND PATHWAYS BETWEEN MATERNAL OBESITY AND CHILDHOOD WHEEZING AND ASTHMA}

Despite the large number of studies reporting associations between maternal obesity and wheezing and asthma in offspring and a number of biologically plausible mechanisms that might explain these findings, the causal relationship is still uncertain. This uncertainty is not trivial as preventing outcomes implies acting on the risk factors that are in the causal chain.

In this section, we summarize some of the main proposed mechanisms and potential pathways by which maternal obesity may increase the risk of wheezing and asthma in offspring.

\section{Maternal obesity as an inflammatory state}

Inflammatory and immunological factors are the most commonly suggested biological mechanism that could explain the link between maternal obesity and childhood wheezing. Obesity is known to be a state of chronic, low-grade systemic inflammation accompanied with increased levels of several proinflammatory factors [38]. Plasma levels of inflammatory markers, including tumour necrosis factor alpha (TNF-a), interleukin 6, and C-reactive protein (CRP) are higher in obese pregnant women compared with pregnant women of normal weight [39].

A parallel increase in inflammatory responses has been observed also in the placenta; this might lead both to a foetal exposure to an inflammatory environment and also to structural changes which might impair placental oxygen diffusing capacity [40,41]. Furthermore, leptin, a pro-inflammatory cytokine, is elevated both in circulation of obese pregnant women and in the cord blood of their children $[42,43]$. Conversely, adiponectine that has been shown to attenuate airways inflammation in animal models [44] has been also reported to have low concentrations both in obese women and in their newborns $[42,45]$. The associations between elevated C-reactive protein in maternal circulation of obese women [46] and early life production of lipopolysaccharide-stimulated TNF-a [35] and wheezing in offspring have been also reported. In addition, excess maternal weight gain in pregnancy is associated with increased early life TNF-a and asthma in childhood [35].

Finally, pregnancy itself represents a condition that modulates the maternal immune system [47], which together with a pro-inflammatory state caused by obesity might affect foetal and infant immune system development and predispose the offspring to later wheezing and asthma.

\section{Dietary patterns in pregnant obese women}

Intake of specific nutrients or different dietary patterns may be linked to maternal obesity that during pregnancy may alter the developing foetus susceptibility to wheezing and asthma in childhood $[48,49]$. However, most of the studies showed weak evidence of the association between maternal dietary patterns and child wheezing [50]. 
Obese women are also more likely to have low serum vitamin D levels [51] and this has been associated with elevated risk of childhood infections and wheezing [52]. Finally, although still speculative the lack of some "anti-inflammatory nutrients", such as probiotics, antioxidants and omega-3 long-chain fatty acids might modulate developmental programming of the infant immune system and increase the risk of asthma and allergy [53].

\section{Obesity and microbiome}

Altered infant gut composition, acting on the immune system development, has been suggested to be a risk factor for later asthma and allergy $[54,55]$. Obesity is related to altered microbial colonization (reduced proportion of Bacteroides) [56], which might alter infant gut colonization and influence the subsequent risk of wheezing and asthma. This is a complex mechanism where several other factors, that are closely related to maternal obesity, such as dietary patterns, some obesity-related pregnancy complications like infections and the associated antibiotic therapy, as well as the mode of delivery influence the diversity and the composition of infant gut and therefore might play a role in this pathway as well.

\section{Obesity-related complications in pregnancy}

Maternal overweight and obesity are the most common high-risk obstetric conditions linked to a number of other both short-and long-term adverse reproductive outcomes. Pre-pregnancy BMI and gestational weight gain are both associated with an increased risk of hypertensive disorders of pregnancy [11]; preeclampsia - a pregnancy induced severe form of hypertension with proteinuria has been associated with wheezing phenotypes [28,57]. Preeclampsia might affect placental development and compromise the developing foetus [58]. In addition, it often results in spontaneous or medically induced preterm delivery and caesarean section, which, in turn, have been associated with an excess of wheezing disorders in offspring [59,60].

\section{Maternal and childhood obesity}

Maternal obesity is associated with rapid foetal growth, large-for-gestational-age infants, and increases the child's own risk of being overweight and obese [11], which in turn has been associated to childhood wheezing and asthma [61]. The relationship between maternal and child's overweight and obesity could be explained by genetic or/and epigenetic imprinting $[62,63]$ shared environmental factors, such as diet and physical activity habits, or foetal programming.

\section{CONCLUSION}

A large number of possible mechanisms, both direct and indirect, have been proposed in order to explain the relationship between maternal obesity and childhood wheezing (Figure 1).

Some of them might be causal while others may act as confounding or mediating factors. Many recent studies, in particular prospective longitudinal birth cohort studies, took into account many of these factors trying to reduce potential confounding. However, it is usually difficult to gather information on all of these potential confounders and, in addition, adjustment for an intermediate factor might bias causal inference. Mediation analysis [31] showed that the relationship between maternal BMI and wheezing is partially mediated by child's overweight/obesity. Moreover, the association between

\section{iris-AperTO}


maternal obesity and increased risk of wheezing in the child may be due to confounding by unmeasured common environmental (e.g. life-style, diet or exercise) or genetic factors as was suggested in a sibling-pair study from Lowe et al. [64].

Finally, the notion that common exposures such as obesity and increased weight gain in pregnancy may have an impact on childhood subsequent common diseases such as wheezing and asthma is in line with the recent attention to epigenetic modifications seen early in life [65].

\section{FUTURE DIRECTIONS}

Given the conflicting data on wheezing and asthma assessed at the school age, future studies should carefully define and analyse the most important confounding factors and potential intermediates. Analyses should also include differential effects by sex and familial history of asthma/atopy.

Further research is needed into the physiological basis and mechanisms for increased risk of wheezing and asthma among children of obese women along with effective interventions to advance the care and prevent the adverse outcomes of obese reproductive age women and their children.

\section{CONFLICT OF INTEREST STATEMENT}

The authors have no conflicts of interest.

\section{REFERENCES}

1. Martinez FD. The origins of asthma and chronic obstructive pulmonary disease in early life. Proc Am Thorac Soc 2009; 6: 272-7.

2. Bracken MB, Belanger K, Cookson WO, Triche E, Christiani DC, Leaderer BP. Genetic and perinatal risk factors for asthma onset and severity: A review and theoretical analysis. Epidemiol Rev 2002; 24: 176-89.

3. Godfrey KM, Barker DJ. Fetal programming and adult health. Public Health Nutr 2001; 4(2B): 61124.

4. Duijts L. Fetal and infant origins of asthma. Eur J Epidemiol 2012; 27: 5-14.

5. Sly PD. The early origins of asthma: who is really at risk. Current Opinion in Allery and Immunol 2011; 11: 24-28.

6. Berg CJ, Mackay AP, Qin C, Callaghan WM. Overview of maternal morbidity during hospitalization for labor and delivery in the united states: 1993-1997 and 2001-2005. Obstet Gynecol 2009; 113: 107581.

7. Kanagalingam MG, Forouhi NG, Greer IA, Sattar N. Changes in booking body mass index over a decade: Retrospective analysis from a glasgow maternity hospital. BJOG 2005; 112: 1431-3.

8. Ng M, Fleming T, Robinson M et al. Global, regional, and national prevalence of overweight and obesity in children and adults during 1980-2013: a systematic analysis for the Global Burden of Disease Study 2013. The Lancet. 2014; 384(9945): 766-781. 
9. Huda SS, Brodie LE, Sattar N. Obesity in pregnancy:prevalence and metabolic consequences. Semin Fetal Neonatal Med 2010; 15: 70-6.

10. Institute of Medicine (US) and National Research Council (US) Committee to Reexamine IOM Pregnancy Weight Guidelines; Rasmussen KM, Yaktine AL, editors. Weight Gain During Pregnancy: Reexamining the Guidelines. Washington (DC): National Academies Press (US); 2009. Available from: http://www.ncbi.nlm.nih.gov/books/NBK32813/ doi: 10.17226/12584

11. Gaillard R, Durmuş B, Hofman A, Mackenbach JP, Steegers EA, Jaddoe VW. Risk factors and outcomes of maternal obesity and excessive weight gain during pregnancy. Obesity (Silver Spring) 2013; 21(5): 1046-55.

12. Rizzo GS, Sen S. Maternal obesity and immune dysregulation in mother and infant: A review of the evidence. Paediatr Respir Rev 2015; 16(4): 251-7.

13. Birthcohorts.Net [homepage on the Internet]. Denmark: Department of Public Health, University of Copenhagen; 2011 [cited 29 April 2016]. Available from: http://www.birthcohorts.net/

14. World Health Organization (WHO). Obesity and overweight: WHO. Fact sheet No. 311. Available at: http://www.who.int/mediacentre/factsheets/fs311/en/. Assessed April 29, 2014.

15. Martinez FD, Wright Al, Taussig LM et al. Asthma and wheezing in the first six years of life. N Engl J Med 1995; 332(3): 133-8.

16. Savenije OE, Granell R, Caudri D et al. Comparison of childhood wheezing phenotypes in 2 birth cohorts: ALSPAC and PIAMA. J Allergy Clin Immunol 2011; 127(6): 1505-12.e14.

17. Brand PL, Baraldi E, Bisgaard H, et al. Definition, assessment and treatment of wheezing disorders in preschool children: An evidence-based approach. Eur Respir J 2008; 32: 1096-1110

18. Håberg SE, Stigum H, London SJ, Nystad W, Nafstad P. Maternal obesity in pregnancy and respiratory health in early childhood. Paediatr Perinat Epidemiol 2009; 23(4): 352-62.

19. Kumar R, Story RE, Pongracic JA et al. Maternal pre-pregnancy obesity and recurrent wheezing in early childhood. Pediatr Allergy Immunol Pulmonol 2010; 23(3): 183-90.

20. Wright RJ, Fisher K, Chiu YH et al. Disrupted prenatal maternal cortisol, maternal obesity, and childhood wheeze. Insights into prenatal programming. Am J Respir Crit Care Med 2013; 187(11): 1186-93.

21. Guerra S, Sartini C, Mendez M et al. Maternal prepregnancy obesity is an independent risk factor for frequent wheezing in infants by age 14 months. Paediatr Perinat Epidemiol 2013; 27(1): 100-8.

22. Leermakers ET, Sonnenschein-van der Voort AM, Gaillard R et al. Maternal weight, gestational weight gain and preschool wheezing: the Generation R Study. Eur Respir J 2013; 42(5): 1234-43.

23. Harpsøe MC, Basit S, Bager P et al. Maternal obesity, gestational weight gain, and risk of asthma and atopic disease in offspring: A study within the Danish National Birth Cohort. J Allergy Clin Immunol 2013; 131(4): 1033-40. 
24. Caudri D, Savenije OE, Smit HA et al. Perinatal risk factors for wheezing phenotypes in the first 8 years of life. Clin Exp Allergy 2013; 43(12): 1395-405.

25. Pike KC, Inskip HM, Robinson SM et al. The relationship between maternal adiposity and infant weight gain, and childhood wheeze and atopy. Thorax 2013; 68(4): 372-9.

26. Eising JB, Uiterwaal CS, van der Ent CK. Maternal body mass index, neonatal lung function and respiratory symptoms in childhood. Eur Respir J 2015; 46(5): 1342-9.

27. de Vries A, Reynolds RM, Seckl JR, van der Wal M, Bonsel GJ, Vrijkotte TG. Increased maternal BMI is associated with infant wheezing in early life: a prospective cohort study. J Dev Orig Health Dis 2014; 5(5): 351-60.

28. Zugna D, Galassi C, Annesi-Maesano I et al. Maternal complications in pregnancy and wheezing in early childhood: a pooled analysis of 14 birth cohorts. Int J Epidemiol. 2015; 44(1): 199-208.

29. Reichman NE, Nepomnyaschy L. Maternal pre-pregnancy obesity and diagnosis of asthma in offspring at age 3 years. Matern Child Health J 2008; 12(6): 725-33.

30. Scholtens S, Wijga AH, Brunekreef B et al. Maternal overweight before pregnancy and asthma in offspring followed for 8 years. Int J Obes (Lond) 2010; 34(4): 606-13.

31. Harskamp-van Ginkel MW, London SJ, Magnus MC, Gademan MG, Vrijkotte TG. A study on mediation by offspring BMI in the association between maternal obesity and child respiratory outcomes in the Amsterdam Born and Their Development Study Cohort. PLoS One 2015; 10(10): e0140641.

32. Forno E, Young OM, Kumar R, Simhan H, Celedón JC. Maternal obesity in pregnancy, gestational weight gain, and risk of childhood asthma. Pediatrics 2014; 134(2): e535-46.

33. Lowe A, Braback L, Ekeus C, Hjern A, Forsberg B. Maternal obesity during pregnancy as a risk for early-life asthma. J Allergy Clin Immunol 2011; 128(5): 1107-9.e1-2.

34. Patel SP, Rodriguez A, Little MP et al. Associations between pre-pregnancy obesity and asthma symptoms in adolescents. J Epidemiol Community Health 2012; 66(9): 809-14.

35. Halonen M, Lohman IC, Stern DA, Ellis WL, Rothers J, Wright AL. Perinatal tumor necrosis factor- $\alpha$ production, influenced by maternal pregnancy weight gain, predicts childhood asthma. Am J Respir Crit Care Med 2013; 188(1): 35-41.

36. Ekström S, Magnusson J, Kull I et al. Maternal body mass index in early pregnancy and offspring asthma, rhinitis and eczema up to 16 years of age. Clin Exp Allergy 2015; 45(1): 283-91.

37. Dumas O, Varraso R, Gillman MW, Field AE, Camargo CA Jr. Longitudinal study of maternal body mass index, gestational weight gain, and offspring asthma. Allergy 2016 Mar 10. doi: 10.1111/all.12876. [Epub ahead of print]

38. Cancello R, Clément K. Is obesity an inflammatory illness? Role of low-grade inflammation and macrophage infiltration in human white adipose tissue. BJOG. 2006; 113(10): 1141-7. 
39. Christian LM, Porter K. Longitudinal changes in serum proinflammatory markers across pregnancy and postpartum: effects of maternal body mass index. Cytokine. 2014; 70(2): 134-40.

40. Zhu MJ, Du M, Nathanielsz PW, Ford SP. Maternal obesity up-regulates inflammatory signaling pathways and enhances cytokine expression in the mid-gestation sheep placenta. Placenta. 2010; 31(5):387-91.

41. Samson JE, Mari G, Dick EJ Jr, Hubbard GB, Ferry RJ Jr, Schlabritz-Loutsevitch NE. The morphometry of materno-fetal oxygen exchange barrier in a baboon model of obesity. Placenta. 2011; 32(11): 845-51.

42. Hendler I, Blackwell SC, Mehta SH, Whitty JE, Russell E, Sorokin Y, Cotton DB. The levels of leptin, adiponectin, and resistin in normal weight, overweight, and obese pregnant women with and without preeclampsia. Am J Obstet Gynecol 2005; 193(3 Pt 2): 979-83.

43. Ferretti G, Cester AM, Bacchetti T, Raffaelli F, Vignini A, Orici F, Martino C, Tranquilli A. Leptin and paraoxonase activity in cord blood from obese mothers. J Matern Fetal Neonatal Med 2014; 27(13): 1353-6.

44. Shore SA, Schwartzman IN, Mellema MS, Flynt L, Imrich A, Johnston RA. Effect of leptin on allergic airway responses in mice. J Allergy Clin Immunol 2005; 115(1): 103-9.

45. Vega-Sanchez R, Barajas-Vega HA, Rozada G, Espejel-Nuñez A, Beltran-Montoya J, Vadillo-Ortega F. Association between adiposity and inflammatory markers in maternal and fetal blood in a group of Mexican pregnant women. Br J Nutr 2010; 104(12): 1735-9.

46. Morales E, Guerra S, García-Esteban R, Guxens M, Alvarez-Pedrerol M, Bustamante M, Estivill X, Antó JM, Sunyer J. Maternal C-reactive protein levels in pregnancy are associated with wheezing and lower respiratory tract infections in the offspring. Am J Obstet Gynecol 2011; 204(2): 164.e 1-9.

47. Halonen M, Lohman IC, Stern DA, Ellis WL, Rothers J, Wright AL. Perinatal tumor necrosis factor- $\alpha$ production, influenced by maternal pregnancy weight gain, predicts childhood asthma. Am J Respir Crit Care Med 2013; 188(1): 35-41.

48. Arck PC, Hecher K. Fetomaternal immune cross-talk and its consequences for maternal and offspring's health. Nat Med 2013; 19(5): 548-56.

49. Chatzi L, Garcia R, Roumeliotaki T, Basterrechea M, Begiristain H, Iñiguez C, Vioque J, Kogevinas M, Sunyer J; INMA study group; RHEA study group. Mediterranean diet adherence during pregnancy and risk of wheeze and eczema in the first year of life: INMA (Spain) and RHEA (Greece) mother-child cohort studies. Br J Nutr 2013; 110(11): 2058-68.

50. Miyake Y, Sasaki S, Tanaka K, Ohfuji S, Hirota Y. Maternal fat consumption during pregnancy and risk of wheeze and eczema in Japanese infants aged 16-24 months: the Osaka Maternal and Child Health Study. Thorax 2009; 64(9): 815-21.

51. Lv N, Xiao L, Ma J. Dietary pattern and asthma: a systematic review and meta-analysis. J Asthma Allergy 2014; 7: 105-21. 
52. Scholl TO, Chen X. Vitamin D intake during pregnancy: association with maternal characteristics and infant birth weight. Early Hum Dev 2009; 85(4): 231-234

53. Camargo CA Jr, Ingham T, Wickens K, Thadhani R, Silvers KM, Epton MJ, Town GI, Pattemore PK, Espinola JA, Crane J; New Zealand Asthma and Allergy Cohort Study Group. Cord-blood 25hydroxyvitamin D levels and risk of respiratory infection, wheezing, and asthma. Pediatrics. 2011; 127(1):e180-7.

54. Palmer DJ, Huang RC, Craig JM, Prescott SL. Nutritional influences on epigenetic programming: asthma, allergy, and obesity. Immunol Allergy Clin North Am 2014; 34(4): 825-37.

55. Johnson CC, Ownby DR. Allergies and Asthma: Do Atopic Disorders Result from Inadequate Immune Homeostasis arising from Infant Gut Dysbiosis? Expert Rev Clin Immunol 2016; 12(4): 37988.

56. Abrahamsson TR, Jakobsson HE, Andersson AF, Björkstén B, Engstrand L, Jenmalm MC. Low gut microbiota diversity in early infancy precedes asthma at school age. Clin Exp Allergy 2014; 44(6): 84250 .

57. Ley RE, Turnbaugh PJ, Klein S, Gordon JI. Microbial ecology: human gut microbes associated with obesity. Nature 2006; 444(7122): 1022-3.

58. Rusconi F, Galassi C, Forastiere F et al. Maternal complications and procedures in pregnancy and at birth and wheezing phenotypes in children. Am J Respir Crit Care Med 2007; 175: 16-21.

59. Steegers EA, von Dadelszen P, Duvekot JJ, Pijnenborg R. Pre-eclampsia. Lancet 2010; 376(9741): 631-44.

60. Sonnenschein-van der Voort AM, Arends LR, de Jongste JC et al. Preterm birth, infant weight gain, and childhood asthma risk: a meta-analysis of 147,000 European children. J Allergy Clin Immunol 2014; 133(5): 1317-29.

61. Rusconi F, Zugna D, Annesi-Maesano I et al. Mode of Delivery and Asthma at School Age in Nine European Birth Cohort. Am J Epidemiol 2016 (in press).

62. Mebrahtu TF, Feltbower RG, Greenwood DC, et al. Childhood body mass index and wheezing disorders: a systematic review and meta-analysis. Pediatr Allergy Immunol 2015; 26: 62-72.

63. van Dijk SJ, Molloy PL, Varinli H, Morrison JL, Muhlhausler BS, Members of EpiSCOPE. Epigenetics and human obesity. Int J Obes (Lond). 2015; 39(1): 85-97.

64. Frazier-Wood AC, Wang Z. Genetics of Obesity. Metabolic Syndrome: A Comprehensive Textbook, Editor: Ahima RS. Springer International Publishing, Switzerland 2016, 123-140.

65. Lowe AJ, Ekeus C, Bråbäck L, Rajaleid K, Forsberg B, Hjern A. Impact of maternal obesity on inhaled corticosteroid use in childhood: a registry based analysis of first born children and a sibling pair analysis. PLoS One. 2013; 8(6):e67368. 
66. Rastogi D, Suzuki M, Greally JM. Differential epigenome-wide DNA methylation patterns in childhood obesity-associated asthma. Sci Rep. 2013; 3: 2164. 
Figure 1. Possible biological mechanisms, confounders and mediators of the relationship between maternal obesity and wheezing and asthma in childhood

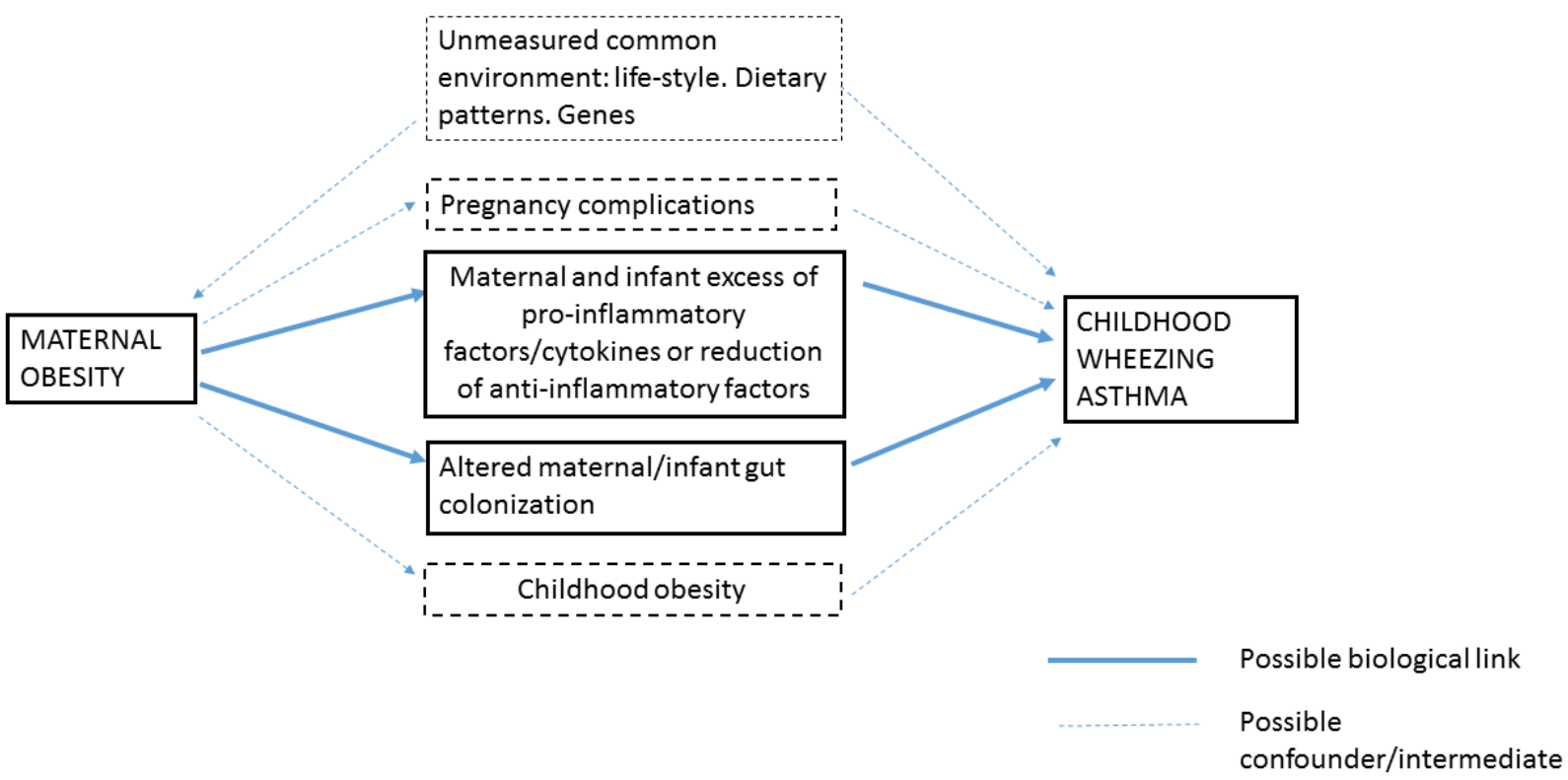

